\title{
Understanding and Responding to the Change of Curriculum in the Context of Indonesian Education
}

\author{
Abdul Muth’im* \\ English Department Faculty of Teacher Training and Education, Lambung Mangkurat University Banjarmasin \\ *Corresponding author: abdulmuthim@yahoo.com
}

Received October 20, 2014; Revised November 17, 2014; Accepted November 23, 2014

\begin{abstract}
The government of the Republic of Indonesia represented by the Ministry of Education and Culture has stipulated that the new curriculum, the 2013 curriculum, should be implemented in all levels of education all over Indonesia starting from 2013-2014 academic year. This change, of course, result in a number of consequences for the stakeholders. One of the stakeholders that will directly experience the consequences most is teachers. The teachers who have begun to feel convenient and be accustomed to with the implementation of the School-Based Curriculum (SBC), suddenly have to shift their mind and teaching practices to this new curriculum. This can make teachers, included English teachers, worried. They are worried if this new curriculum is more complicated to implement than the previous one, the SBC. Actually, the change of curriculum is something common in the world of education. In Indonesia, every eight to nine or ten years, a curriculum changes. That is why the change of curriculum should not be understood as something extraordinary; rather, it should be understood as something common. This perception is important because the way to understand the change of curriculum will influence the way to respond it. If it is thought of as something extraordinary, it should be responded in extraordinary way too. However, if it is considered as a common something it will make teachers' job be more proportional as well as more professional. This paper tries to discuss and explore the essence of curriculum in general and suggest how Indonesian teachers should respond to the new curriculum, the 2013 curriculum within the context of Indonesian education.
\end{abstract}

Keywords: curriculum, education, SBC, the 2013 curriculum

Cite This Article: Abdul Muth'im, "Understanding and Responding to the Change of Curriculum in the Context of Indonesian Education." American Journal of Educational Research, vol. 2, no. 11 (2014): 1094-1099. doi: 10.12691/education-2-11-15.

\section{Introduction}

The era of the implementation of SBC is ended by the implementation of the new curriculum, called the 2013 curriculum. As usual, when a new curriculum is launched reactions from various groups and sub-groups of community such as: education observers, non-government organizations (NGOs), politicians, parents, etc., arise. Unfortunately, the reactions seem to be mostly negative. They perceive that every time a new Minister of National Education and Culture commences his or her official assignments, there is a tendency to change or replace the curriculum being used. They also accuse that the reason of replacing the SBC with the 2013 curriculum is not clear. Other negative reaction is that they are doubtful of teachers' readiness to implement the new curriculum. Yet, the change of curriculum does not happen only this time. Before SBC was implemented some curricular such as the 1968 curriculum, the 1975 curriculum, the 1984 curriculum, the 1994 curriculum, and the 2004 curriculum had already been implemented in Indonesia. The reasons put forwarded by the Ministry of Education and Culture of the Republic of Indonesia to replace the SBC with the 2013 curriculum are: the current global challenges, required competencies, current negative phenomena especially among young people, and discouraging perceptions among Indonesians regarding education (quoted by Hamied, 2014).

In response to the implementation of this new curriculum, it is suggested for all Indonesian teachers of all school subjects to understand the essence of curriculum in general and especially to understand the 2013 curriculum profoundly and comprehensively, and to continuously improve and maintain their professionalism as teachers.

\section{Understanding the Essence of Curriculum}

Understanding the essence of curriculum is the first thing a teacher should to enable him or her to respond to the change of curriculum proportionally and professionally. Different experts define curriculum in different way. Richards (2001) defines curriculum as something that includes the processes that are used to determine the needs of a group of learners, to develop aims or objectives for a program to address those needs, to determine appropriate syllabus, course structure, teaching 
methods, and teaching materials, and to carry out an evaluation of the language program that results from these processes. Finocchiaro (1989, p.205) defined curriculum as "the knowledge, information, skills, activities, materials, etc. which are included in the teaching of any subject". Doll (in Prabawa and Ariatmi, 2002, p.78), defines curriculum as “... all the experiences which are offered to learners under the out spaces or direction on the school.

From the above definitions it can be concluded then that a curriculum essentially contains three basic components, namely, (a) the educational aim of the program (as the ends), (b) the content, teaching procedures and learning experiences which will be needed to achieve this objective (as the means), and (c) some instruments for assessing whether the educational ends have been achieved or not (as the assessment).

\section{(a) Educational Objectives}

According to the Act No. 20 of 2003 regarding National System of Education of Indonesia, all education programs and activities are addressed for the sake of the attainment and realization of national objectives in the field of education. The objectives of national education, according to the act, are to develop the potentials of the students to become faithful and devoted human beings to God the Almighty, to have respectful morality, to be healthy, to be well-informed, to be skillful, to be creative, to be selfreliance, and to become democratic and responsible citizens.

In the system of Indonesian education, the national objectives are then hierarchically translated by the institutions that run program of education into institutional objectives, curricular objectives, and instructional objectives.

Each institution of education has its own curriculum with its own objectives. The curriculum of institution that runs a program of educating students to become lawyer or attorney is different from the curriculum of institution that runs a program of educating students to become doctor or nurse, so is the curriculum of institution that runs a program of educating students to become teacher is also different from the institution that runs a program of educating students to become engineer.

Within an institution of education a number of subjectmatters are taught for the students, such as national ideology, religion, Indonesian language, English language, sport, and so forth. English, for instance, is taught for Junior High School (JHS) students as well as Senior High School (SHS) students. Based on English curriculum of the 2004, the objective of teaching and learning English in JHS is to help the students reach a competency standard to communicate fluently and accurately in spoken or written English which is appropriate to its social context, whereas the objective of teaching English for SHS is to help the students reach a competency standard to communicate fluently and accurately in spoken or written English by using appropriate modes of language.

Instructional objective is the last objective of education in the hierarchy. It is the objective which will be reached in and within one session of teaching and learning activities. In SBC this instructional objective is the attainment of what is called Competency Standard (CS) and Basic Competency (BC). Based on CS/BC, a teacher chooses the suitable instructional materials, uses the appropriate procedures of teaching and learning, and applies the right means of assessment.

\section{Content, Teaching Procedures and Learning Experiences}

\section{- Content}

The other important aspect of a curriculum that a teacher is supposed to understand is the content of the teaching materials. Understanding the content teaching materials implies that a teacher knows how teaching materials are selected, sequenced, and justified (Nunan, 2003). It is this selection, sequence, and justification of teaching materials which is called syllabus. Syllabus, in accordance with Krahnkle, "specifies the content of the lessons used to move the learners toward the goals" (Krahnkle, 1987:2). To determine the content of teaching materials, a number of questions may be asked as a guideline. For instance, "what kind of instructional material that is suitable with the objective"; "what kind of instructional material which is suitable with the level of students"; "what kind of instructional material that is suitable with certain skill of language", or "what kind of instructional material which is suitable with certain function of language”.

The answers to those questions will lead to the kind of syllabus that will be used. Krahnkle categorized the kinds of language syllabus into six, namely: (1) structural (formal) syllabus, (2) notional/functional syllabus, (3) situational syllabus, (4) skill-based syllabus, (5) taskbased syllabus, and (6) content-based syllabus (Krahnkle, 1987). The six kinds of syllabus are then elaborated as follows.

Structural (formal) syllabus is a syllabus in which the content of language teaching is a collection of the forms and structures, usually grammatical, of the language being taught. Notional/functional syllabus is a syllabus in which the content of the language teaching is a collection of the functions that are performed when language is used, or the notions that language is used to express. Situational syllabus is a syllabus in which the content of language teaching is a collection of real or imaginary situations in which language occurs or is used. Skill based-syllabus is a syllabus in which the content of the language teaching is a collection of specific abilities that may play a part in using language. Task-based syllabus is a syllabus in which the content of the teaching is a series of complex and purposeful tasks that the students want or need to perform with the language they are learning. Content-based syllabus is a syllabus in which the content or information is taught using the language the students are also learning (Krahnkle, 1987). So, in order to be able to choose the right and appropriate instructional material which is suitable with instructional objective, the ability to select and to grade the instructional material properly is a must. If the teacher does not have the ability, it is possible that instructional material chosen is not suitable with instructional objective.

\section{- Teaching Procedures}


Understanding the teaching procedure is another important component of understanding a curriculum. In my opinion, teaching procedures are closely related with the approach, the method and the technique used by a teacher in fulfilling his or her job as a teacher. As it is understood that "an approach is a set of correlative assumptions dealing with the nature of language teaching and learning", whereas "a method is an overall plan for the orderly presentation of language material" and "a technique is a particular trick, strategem, or contrivance used to accomplish an immediate objective" (Anthony in Richards and Rodgers, 1986:15). Of the approaches, methods, and techniques which are very famous among English teachers are: Natural Approach (NA), Direct Method (DM), Audio-lingual Method (ALM), Grammar Translation Method (GTM), Communicative Language Teaching (CLT), and Total Physical Response (TPR).

\section{- Learning Experience}

This is related with what the learning experience the students should get involved in and how it is internalized. A number of questions may be helpful, for example, "Is the learning experience developed by involving the students in individual tasks, in pair, in group, or in unison?”; “Is learning experience developed by involving students in class activity or by involving students through outside activity?"; “Is learning experience developed through teacher centered instruction or is learning experience developed through students-centered activity?”. All these questions are useful in determining what kind of learning experience to be developed and how the learning experience can be developed. Of course, deciding a suitable learning experience for the students is not easy. Adequate knowledge and skill are needed by the teacher. Otherwise, the learning experience he or she offers may not reach its goal, that is, the objective of an instruction.

Though curriculum 2013, in accordance with Agustien, is different from the previous curriculum, the SBC, it still "adopts a Genre Based-Approach (GBA) which aims to develop the ability to communicate in both spoken and written language” (Agustien, 2014:14). To realize this objective she recommends taking into account the five cycles proposed by Derewianka: (1) building knowledge of the topic, (2) learning about the text type, (3) guided practice in using the text type, (4) independent use of the text type, and (5) reflecting on the text type and its use.

For the purpose of Indonesian teacher training, the cycles proposed by Derewianka above are simplified into four cycles, namely, building knowledge of the field (BKoF), modeling of the text (MoT), joint construction of the text (JCoT), and individual construction of the text (ICoT). In BKoF a teacher digs up his or her students' background knowledge about the text especially about its generic structure and its lexico-grammar. This is important because it is claimed that the students who have background knowledge of the unit or the topic taught will learn better that the students who do not have background knowledge (Departemen Pendidikan Nasional, 2005).

In MoT phase, the students either in pair or in group discuss the text they have and match the generic structure and the lexico-grammar of the text with the text discussed earlier. Every pair or every group, through the pair or the group representative presents the result of the discussion of his/her pair/group. Other pairs or other groups give their opinion to the presentation (Departemen Pendidikan Nasional, 2005).

Based on the model given by the teacher and pairs or groups presentation, the next step the students should do is making their own text in pair or in group (JCoT). The text they produce in pair or in group is then presented in front of the class. The students then discuss and assess the text whether it meets the characteristics of the text in term of its generic structure and in terms of its lexico-grammar by referring to the model they previously had (Departemen Pendidikan Nasional, 2005).

The last step the students should do is to create their own text (ICoT). This task is intended to check whether the knowledge and experience they have before is successfully understood, whether the model shown and discussed give clear picture about the concept and whether the text produced by the pairs and the groups in class inspire him/her to create his/her own text individually. In other words, whether the learning experience they have had can be internalized by each student. The text one student produce is then presented and discussed in the class to get feedback from other students and the teacher (Departemen Pendidikan Nasional, 2005).

\section{Means for Assessing Educational Objectives}

The other component of a curriculum a teacher should understand is knowing how to assess students learning. Assessment is a broad term that encompasses the general process of collecting, synthesizing and interpreting formal and informal data which provide comprehensive information about individual or group achievement over time. Assessment may be performed through testing and it may also be performed through non-testing technique such as observation of performance, portfolios, or interviews (Miller, 2008).

Testing is a formal assessment instrument used to judge students' cognitive ability in an academic discipline as well as to gather quantitative information about students' psychomotor performance and affective characteristics. There are two different categories of test items used in educational settings: objective and subjective. Objective items require students to select the correct response from two or more choices, whereas subjective test items require students to construct their own responses to test questions or statements rather than selecting from among several possible answers (Miller, 2008). Either one which is chosen, it should meet two conditions: valid and reliable. Harmer (2003) claims that a test is valid if it tests what it is supposed to test, and it is reliable if the result is consistent.

Whatever assessment is used the goal remains the same, that is, it is intended to (1) evaluate and improve student learning, (2) identify student strength and weaknesses, (3) assess the effectiveness of a particular instructional strategy, (4) evaluate and improve the effectiveness of curriculum programs, (5) evaluate and improve teaching effectiveness, and (6) communicate with parents and guardians and involve them in their children's learning (Kellough, 1993, p.319-320). 


\section{Responding to the Change of Curriculum}

In order to be able to respond to the change of curriculum properly and appropriately, one thing that a teacher should keep in mind is: continuously developing and maintaining his or her professionalism. Without this awareness, it is quite hard to respond to the change of curriculum that is happening in Indonesian education recently properly and appropriately.

\section{Teachers' Professionalism}

Teaching profession is not just a job. That is why teaching profession, like other professions such as doctor, engineer, painter, sculptor, and the like, cannot and may not be done by anyone whose bases are just spirit and readiness to be teacher, let alone if the reason is because of there is no other job vacancy available. In short it can be said that teaching profession should be done by someone who is specially trained or someone with a particular skill because it involves a high level of education. It is no wonder then that this kind of person is called a professional.

To become a professional teacher, for instance, one must undergo an education that prepares and equips him or her for that purpose. A professional teacher, in accordance with Hamalik should meet a number of conditions. He or she should master the principles of education, be able to plan teaching and learning program, be able to manage classroom interaction, master various kinds of teaching method, be able to assess students' achievement objectively, be familiar with the function and program of counseling service at school, be familiar with school administration management, and be able to comprehend and translate the results of research in the field of education for the purpose of teaching improvement (Hamalik, 2004).

Why should a professional teacher master the principles of education? Though the principles of education for different levels of education applied in different regime and different era might not be same, mastering the principles of education is a must for a professional teacher. This is because they lay the philosophy of education, the philosophy of teaching and the philosophy of learning. By understanding the principles of education well, teachers will be able to do their profession professionally.

Why should a professional teacher be able to plan teaching and learning program? In other words, why should a professional teacher understand and be able to translate curriculum into a practical program of education well. A curriculum should become a guide line for a teacher in planning his or her teaching and learning program because it contains the ENDS of educational purpose of the programme, the MEANS to help students achieve the ends in the form of content, teaching procedures and learning experiences, and ASSESSMENTS, i.e. some means for assessing whether or not the educational ends have been achieved (Richards et al. (1987).

Why should a professional teacher understand and be able to translate a curriculum, whatever the curriculum is, into a practical program is a must for a teacher. For example, present teachers who apply the SBC are requested to understand and be able to translate the objective(s) of the teaching and learning program nationally stated by our government in the form of CS and BC into indicators of learning and learning objectives. Based on these indicators of learning and learning objectives, the teachers will then choose and select suitable instructional material, approach, method, and techniques which are believed to enable them to help their students to reach the objectives of teaching and learning. To check whether the instructional material chosen, the approach, the method, and the technique(s) implemented result in the maximum attainment of objective(s) of the teaching and learning program, a suitable means of assessment should be provided.

Why should a professional teacher be able to manage classroom interaction? As it is known that a classroom consists of a number of students whose personal backgrounds such as their learning capabilities, learning styles, and characters are never the same? In learning styles, for instance, there are at least three categories of learners: reception, construction, and co-construction (Watkins, et al., 2007). The first category of learners is concerned with quantity, facts and skills. This model of learning assumes that transmission of knowledge is from an external source (e.g. teacher). Emotional and social aspects are not attended to. In this view learning means being taught. The second category of students is those who are concerned with the learner's construction of meaning through discussion, open-ended learning, and making connection. Learning in accordance with this view is individual sense-making. The third category of students is those who are concerned with the learner's construction of meaning through interaction and collaboration with others, especially through dialogue. In this view, learning is understood as building knowledge with others. That is why a teacher should be professional in managing these differences, so that he will be able to help his students reach the objective(s) of teaching and learning program maximally. The purpose of managing classroom is to enable the maximum attainment of learning achievement. Students are unique with their own characteristics, learning capabilities, learning styles, etc.

Why should a professional teacher master various kinds of teaching method. Method in accordance with Richards and Rodgers (1986) is theoretically related to an approach, is organizationally determined by design, and is practically realized in procedure. However, as it is also known that different subject matter has its own characteristics. The method of teaching English, for example, is different from the method of teaching Mathematics or Physics. That is why an English teacher must be familiar with and be able to implement various methods of teaching English as mentioned earlier. More importantly, an English teacher, in addition to be familiar with those methods, should also know the characteristics of each of the methods and should know when they are implemented so that the objectives of learning can be achieved maximally.

Why should a professional teacher be able to assess students' learning achievement? Having this ability is as important as having the ability of choosing and selecting the appropriate instructional material, the implementation 
of suitable method, technique, strategies of teaching and the like. To check whether the objective(s) of teaching and learning using the chosen and selected instructional material, and the method, the techniques, the strategies implemented help students to reach the objective(s) of teaching and learning program, a right assessment should be provided. The assessment may take different form: test and non-test. In general, however, an assessment is administered to fulfill various purposes: to evaluate and improve student learning, to identify student strengths and weaknesses, to assess the effectiveness of a particular instructional strategy, to evaluate and improve the effectiveness of curriculum programs, to evaluate and improve teaching effectiveness, and to communicate with parents and guardians and involve them in their children's learning (Kellough, et al., 1993). All the aspects should be assessed objectively. This means that the result of assessment should really describe what students learn.

For a language teacher, in addition to have the above characteristics, he or she should also meet other conditions stipulated for a good language teacher. According to Brown, a good English teacher should be in good in four areas: technical knowledge, pedagogical skills, interpersonal skills, and personal qualities (Brown, 2007). These four characteristics are then elaborated as the following.

Technical knowledge requires an English language teacher to understand the linguistic systems of English phonology, grammar, and discourse; comprehensively grasp basic principles of language learning and teaching; have fluent competence in speaking, writing, listening, and reading English; know through experience what it is like to learn a foreign language; understand the close connection between language and culture, and keep up with the field through regular reading and conference/workshop attendance (Brown, 2007).

Pedagogical skills necessitate a language teacher to have a well-thought-out, be informed approach to language reading; understand and use a wide variety of techniques; efficiently design and execute lesson plans; monitor lessons as they unfold and make effective midlesson alterations; effectively perceive students' linguistic needs; give optimal feedback to students, stimulate interaction, cooperation, and teamwork in the classroom; use appropriate principles of classroom management; use effective, clear presentation skills; creatively adapt textbook material and other audio, visual, and mechanical aids; innovatively create brand-new materials when needed; and use interactive, intrinsically motivating techniques to create effective tests (Brown, 2007).

Interpersonal skills require a language teacher to be aware of cross-cultural differences and is sensitive to students' cultural traditions; enjoy people, show enthusiasm, warmth, rapport, and appropriate humor; value the opinions and abilities of students; be patient in working with students of lesser ability; offer challenges to students of exceptionally high ability; cooperate harmoniously and candidly with colleagues (fellow teachers); and seek opportunities to share thoughts, ideas, and techniques with colleagues (Brown, 2007).

Personal qualities necessitate a language teacher to be well organized, conscientious in meeting commitment, and dependable; be flexible when things go awry; maintain an inquisitive mind in trying out new ways of teaching; set short-term and long-term goals for continued professional growth; and maintain and exemplify high ethical and moral standards (Brown, 2007).

\section{Continuous Development of Teacher's Professionalism}

Of course the one who is mostly responsible for the development of teacher's professionalism is the teacher him/herself. To support their knowledge teachers should keep up with the field through regular reading and conference/workshop attendance. In the past, buying textbooks or attending conference or workshop that charges payment might be beyond the teachers' capability. This is because of the salary they got at that time was not enough to afford them. However, the situation is changing now. By the additional income they get from teacher certification, teachers may spare some amount of money for these purposes.

Attending meeting held by a group of teachers of the same field regularly is another worthdoing to develop teachers' professionalism. Through the meeting, a teacher may get solution of the problem he or she faces in his class from other colleagues. They may also learn new ideas, methods and strategies of teaching shared by other teachers.

Getting involved in workshop or training in the field is another appreciated effort to do. Regularly, the Ministry of Education and Culture holds workshop and training for teachers on related fields. However, since the number of teachers are so large while the fund is limited, not all teachers have the chance to get involved in this training and education. This weakness can be overcome by this strategy. Headmaster can assign the teachera(s) who attended the workshop or training to dissimenate it to their colleagues. There are two advantages that can be benefited from this. First, it will train the teacher who attended the workshop or training to be more skillful in the field. Second, other teachers who do not have chance to attend the workshop or training will get the same benefit too, without leaving their students and family.

Other thing that should also be done, if is not yet, is making the role of headmaster more effective. Headmaster should regularly check if the teachers have made scenario of their lesson plan. And if it is necessary, once in a while he does incognito visit to a class to see a teacher teaching. In this occasion, he may find out whether what has been planned by a teacher is approximately executed or not. By doing this, I believe, in the long run, there will not be any more teachers coming into the class without any preparation.

School supervisor is the other part that is also responsible for the development of professionalism of teachers. One of the tasks of superintendent is to give guidance for the teachers to improve their teaching practices. To make supervision and guidance more effective, ecruitment of superintendent should also be considered thoroughly and comprehensively. An ideal superintendent, should be selected from senior and experienced teachers, not from young and unexperienced ones. This is important to consider because a superintendent does not only deal with supervision business but also deals with psychological matters. Young 
and unexperienced superintendent might have problem in supervising “old and experienced teachers”. Especially for eastern people like Indonesians, most of youngsters are still "ewuh-pakewuh" (feel uneasy) to give suggestion and guidance to old people though they know it is good for them.

\section{Conclusion}

From the discussion above it can be concluded that the change of curriculum may be perceived as something very complicated that may result in frustration for most teachers but it may also be perceived as something new that challenges teacher to exploit his or her knowledge, skill and creativity to make teaching and learning more enjoyable and more productive. However, it must be born in mind that how to respond to the change of curriculum depends very much on the way it is perceived. Do we want to make complicated or do we want to make it simple? To conclude this paper let us say "Welcome the 2013 curriculum”.

\section{References}

[1] Act No. 20 of 2003 Regarding National System of Indonesian Education (Undang-Undang No. 20 Tahun 2003 tentang Sistim Pendidikan Nasional).

[2] Agustien, Helena I.R. (2014). The 2013 English Curriculum: The Paradigm, Interpretation and Implementation. Dalam Handoyo Puji Widodo dan Nugrahaeny T. Zacharias (Eds). Recent Issues in English Language Education: Challenges and Directions. Bandung: The Association of Teaching English as a Foreign Language in Indonesia (TEFLIN).

[3] Brown, H. Douglas. ( 2007). Teaching by Principles: An Interactive Approach to Language Pedagogy. White Plains, New York.

[4] Departemen Pendidikan Nasional. (2004). Kurikulum 2004 Standar Kompetensi Mata Pelajaran Bahasa Inggris untuk Sekolah Menengah Pertama dan Madrasah Tsanawiyah. Jakarta.
[5] Departemen Pendidikan Nasional. (2004). Kurikulum 2004 Standar Kompetensi Mata Pelajaran Bahasa Inggris untuk Sekolah Menengah Atas dan Madrasah Aliyah. Jakarta.

[6] Departemen Pendidikan Nasional Direktorat Pendidikan Lanjutan Pertama Direktorat Jenderal Pendidikan Dasar dan Menengah. (2005). Materi Pelatihan Terintegrasi Bahasa Inggris Buku 2. Jakarta.

[7] Finocchiaro, Mary. (1989). English as a Second Language: from Theory to Practice. New York: Regents Publishing Company.

[8] Hamalik, Oemar. (2004). Pendidikan Guru Berdasarkan Kompetensi. Bandung: Bumi Aksara.

[9] Hamied, Fuad Abdul. (2014). Curriculum Change: What does it mean to Indonesian TEFL? Dalam Handoyo Puji Widodo dan Nugrahaeny T. Zacharias (Eds). Recent Issues in English Language Education: Challenges and Directions. Bandung: The Association of Teaching English as a Foreign Language in Indonesia (TEFLIN).

[10] Harmer, Jeremy. 2003. The Practice of English Language Teaching. Third Edition. Printed in Malaysia. Longman.

[11] Kellough, Richard et al. (1993). Middle School Teaching: Methods and Resources. New York: Macmillan Publishing Company.

[12] Krahnke, Karl. 1987. Approaches to Syllabus Design for Foreign Language Teaching. Englewood Cliffs, NJ: Prentice Hall Regents.

[13] Miller, Patrick W. (2008). Measurement and Teaching. Munster, Indiana. Patric W. Miller and Associates.

[14] Nunan, David (Ed). 2003. Practical English Language Teaching. New York: McGraw Hill.

[15] Richards, Jack C. (2001). Curriculum Development in Language Teaching. New York: The Press Syndicate of the University of Cambridge.

[16] Richards, Jack C. and Rodgers, Theodore S. (1986). Approaches and Methods in Language Teaching. Cambridge: Cambridge University Press.

[17] Richards, Jack C. et al. (1987). Longman Dictionary of Applied Linguistics. Essex, England: Longman Group Limited.

[18] Peraturan Pemerintah Republik Indonesia Nomor 32 Tahun 2013 tentang Perubahan atas Peraturan Pemerintah Nomor 19 tahun 2005 Standar Nasional Pendidikan.

[19] Prabawa, Andi Haris dan Siti Zuhriah Ariatmi (ed). (2002). Paradigma Pengembangan Kurikulum Pendidikan Tinggi Tahun 2000. Surakarta: Muhammadiyah University Press.

[20] Watkins, Chris; Carnell, Eileen \& Lodge, Caroline. 2007. Effective Learning in Classroom. London: Paul Chapman Publishing. 